\title{
Maternal attitudes, beliefs and practices related to the feeding and nutritional status of schoolchildren
}

\author{
Atitudes, crenças e práticas maternas em \\ relação à alimentação e ao estado nutricional \\ de crianças em idade escolar
}

Jéssica PEDROSO 1 (ID) 0000-0001-5446-4319

Natacha TORAL 1,2 (D) 0000-0003-0297-2340

Muriel Bauermann GUBERT1,2 ID 0000-0002-0103-4187

A B S T R A C T

\section{Objective}

To analyze the relationship between the maternal attitudes, beliefs and practices and the children's food consumption and nutritional status.

\section{Methods}

A cross-sectional study of 563 mother-child pairs. Mothers answered an online questionnaire that collected the following information: sociodemographic data, maternal nutritional status, the child's food consumption (evaluated through the Food Frequency Questionnaire and the School Child Diet Index), and maternal attitudes, beliefs and practices about the schoolchildren's eating (assessed through the Child Feeding Questionnaire). Children had their anthropometric measurements evaluated for the interpretation of the nutritional status.

1 Universidade de Brasília, Faculdade de Ciências da Saúde, Programa de Pós-Graduação em Nutrição Humana. Brasília, DF, Brasil.

2 Universidade de Brasília, Faculdade de Ciências da Saúde, Departamento de Nutrição. Campus Universitário Darcy Ribeiro, 70910-900. Brasília, DF, Brasil. Correspondence to: J PEDROSO. E-mail: <jessicapedroso1211@gmail.com>.

Support: Coordenação de Aperfeiçoamento de Pessoal de Nível Superior (Protocol No.001).

Article based on the dissertation by J PEDROSO, entitled "Atitudes, crenças e práticas maternas sobre alimentação infantil e percepção e insatisfação materna em relação ao estado nutricional de crianças em escolas particulares do Distrito Federal, Brasil”. Universidade de Brasília; 2016.

How to cite this article

Pedroso J, Toral N, Gubert MB. Maternal attitudes, beliefs and practices related to schoolchildren feeding and nutritional status. Rev Nutr. 2019;32:e180184. http://dx.doi.org/10.1590/1678-9865201932e180184 


\section{Results}

Mothers who considered their children to be bigger (ORaj=6.60) and who worried more about their children's weight (ORaj=3.47) presented greater chances of having overweight children. Mothers with a greater perception of responsibility $(\mathrm{ORaj}=0.57)$ and who put more pressure in their children to eat $(\mathrm{ORaj}=0.38)$ presented lower chances of having overweight children. The majority of children consumed high-quality food (77.4\%). Mothers who more closely monitored their children's food consumption were 2.79 times more likely to have their children eating high-quality food.

\section{Conclusion}

Nutritional interventions should focus on stimulating the parents' sense of responsibility for the child's nutrition, as well as on promoting the frequent monitoring of the child's food intake.

Keywords: Child. Food consumption. Mother-child relations. Nutritional status.

\section{RE S U M O}

\section{Objetivo}

Analisar a relação entre as atitudes, crenças e práticas maternas e o consumo alimentar e o estado nutricional da criança.

\section{Métodos}

Estudo transversal com 563 pares mães-crianças. Mães responderam questionário online que coletava as seguintes informações: dados sociodemográficos, estado nutricional materno, consumo alimentar da criança (avaliado a partir do Questionário de Frequência Alimentar e do Índice de Alimentação do Escolar), e atitudes, crenças e práticas maternas sobre a alimentação de crianças em idade escolar (avaliadas a partir do Questionário de Alimentação da Criança). As crianças tiveram suas medidas antropométricas aferidas para interpretação do estado nutricional.

\section{Resultados}

Mães que percebiam os corpos de suas crianças maiores $(O R a j=6,60)$ e que se preocupavam mais com o peso da sua criança $(O R a j=3,47)$ apresentavam maior chance de terem filhos com excesso de peso. Mães com maior percepção de responsabilidade $(O R a j=0,57)$ e que pressionavam mais a criança para comer $(O \operatorname{Raj}=0,38)$ apresentavam menor chance de terem crianças com excesso de peso. A maioria das crianças possuía uma alimentação de alta qualidade $(77,4 \%)$. Mães que monitoravam mais a alimentação de sua criança tiveram a chance 2,79 vezes maior de ter criança com alimentação de alta qualidade.

\section{Conclusão}

As intervenções nutricionais devem focar em estimular o senso de responsabilidade dos pais pela nutrição da criança, bem como em promover o monitoramento frequente do consumo alimentar da criança.

Palavras-chave: Criança. Consumo de alimentos. Relações mãe-filho. Estado nutricional.

\section{NTRO D U CTION}

Family is known to be a strong influence on a child's lifestyle and eating habits, and is responsible for both the quality and quantity of available food and for the social context of the child's meals [1-4]. Therefore, parents should recognize their importance in the nutrition of their offspring and encourage their children to maintain healthy eating habits, as appropriate food consumption is extremely important for a child's growth and development [5].

Parental attitudes towards the feeding of their children are affected by various factors, such as the child's physical appearance, age, sex, birth order, and nutritional status $[4,6]$. Restrictive behaviors and pressure to eat are two forms of parental practices that aim to either stimulate or restrict the consumption of some kinds of foods, depending on what parents consider appropriate or healthy $[7,8]$. These attitudes can influence a child's food consumption for the rest of her or his life. 
Excessively restrictive behaviors towards unhealthy food can lead children to consume increased amounts of those foods when they are available, and are thus associated with childhood overweight [7-10]. They can also harm a child's caloric intake regulation, strengthen their preference for prohibited food, or lead to the adoption of restrictive diets and to a higher prevalence of eating disorders [7].

On the other hand, pressuring a child to eat can mask their internal signs of hunger and satiety, which leads children to regulate their eating habits through external stimulation, such as predetermined times for meals and fixed size of portions $[7,8,11]$.

Despite the importance of this thematic, studies that address these issues in Brazil are scarce. Thus, the present study makes a novel contribution to the existing literature, since it aims to analyze the relationship between maternal attitudes, beliefs and practices and the children's food consumption and nutritional status.

\section{METHODS}

A cross-sectional study of pairings of mothers and their children from 19 private schools in the Federal District, Brazil, was conducted in 2015. The sample calculation considered the total number of students enrolled in the first, second, or third grade of private elementary schools of the region in 2013. The sample (which included a minimum of 474 mother-child pairs) was representative of students from first to third grade of private elementary schools, with a maximum error of $5 \%$ and a 95\% Confidence Interval (CI).

Since families with higher incomes and educational levels in Brazil tend to send their children to private schools, using those schools for the study led to mothers who are more likely to have access to the Internet and to understand the questionnaire without needing any assistance when filling them in. However, it was expected that the high socioeconomic level of the study sample would not influence the results of the study, since the family income and maternal educational level were included as covariates in the models.

Schools were chosen for participation in the study through a previously elaborated random list of all the private schools in the Federal District. They were invited following the order on this list until the sample size was reached. All the students from the first, second, or third grade of the elementary schools and their mothers were invited to join the research. Only children who lived with their mothers, however, were included in this study.

The exclusion criteria were: mother-child pairs in which mothers were pregnant (because of the maternal weight gain during pregnancy); mother-child pairs in which the child presented pathologies that influenced directly her or his food consumption (diabetes mellitus, phenylketonuria, celiac disease); presence of pathologies directly related to the nutritional status (errors of metabolism, Turner syndrome, Hashimoto Thyroiditis, Hypothyroidism); or physical incapacities that could limit anthropometric evaluation. During the analysis, mother-child pairs in which children did not have their height and weight measured or in which mothers did not fully answer the online questionnaire were excluded.

The schools sent out invitations to the mothers by letter and/or e-mail. These contained a link to the online questionnaire - available at the Survey Monkey ${ }^{\odot}$ (San Mateo, United States) platform - as well as a code that allowed the researchers to link the anthropometric data of their children (weight and height) to the questionnaire they answered. 
Mothers agreed to their and their child's participation in the survey through an online consent form. The participation of their children also required the child's consent to collect their anthropometric data. The Research Ethics Committee of the School of Health Sciences at the Universidade de Brasilia (UnB, University of Brasilia) approved the research, protocol No.39116314.3.0000.0030.

\section{Anthropometric evaluation}

The child's height and weight measurements were collected at the schools, using a calibrated weighing scale Dayhome ${ }^{\circledast}$ (São Paulo, Brazil) with a maximum capacity of $150 \mathrm{~kg}$ and a sensitivity of $0.1 \mathrm{~kg}$, and a stadiometer Stanley ${ }^{\circledast}$ (New Britain, United States) with a capacity of 2 meters, divided in centimeters). The AnthroPlus software (Genebra, Switzerland) was used to calculate the Body Mass Index for age (BMI/age) in Z-scores [12]. The cut-off points used were <-2 Standard Deviation (SD) for underweight, >+1SD for overweight and >+2SD for obese individuals.

\section{Questionnaire}

A pilot study was conducted to ensure the questionnaire's suitability prior to its release. This study was based on mother-child pairs of unselected private elementary schools. The questionnaire collected sociodemographic data, information on the child's food consumption, the mother's nutritional status, and her attitudes, practices, and beliefs about child feeding. Sociodemographic data included family income, the child's age and sex, and the mother's age, educational level, marital status, and skin color.

For the evaluation of the mothers' BMI, self-reported weight and height measurements were used. The BMI was calculated and classified according to the following cut-off points: BMl<18.5 for underweight, $\geq 25 \mathrm{~kg} / \mathrm{m}^{2}$ for overweight, and $\geq 30 \mathrm{~kg} / \mathrm{m}^{2}$ for obese individuals.

Children food consumption was evaluated using the Food Frequency Questionnaire (FFQ) developed by Molina et al. [13] for Brazilian children. The FFQ evaluates breakfast habits and the consumption rate of varied foodstuffs. The quality of the children's food consumption was evaluated using the School Child Diet Index (SCDI, 2010), based on the frequency of consumption of breakfast and healthy and unhealthy foods obtained with the FFQ.

The SCDI assigns a score to each child (ranging from -15 to 16 points) considering the nutritional recommendations in Brazil [14]. Children received one point if they had breakfast every day, and one extra point per type of food consumed, if consumed: fruits, raw salad, cooked vegetables, beans, natural fruit juice, or milk every day; fish at least once a week; sweets or candies, crackers, soda pops, or baked or fried savories twice or fewer times a week; fried foods (French fries, fried manioc or fried banana) once or fewer times a week; hamburgers, mayonnaise, or instant noodles less than once a week. Similarly, one point was subtracted if the child did not regularly have breakfast or if she or he ate: fruits twice or fewer times a week; milk, raw salad, or cooked vegetables less than 4 times a week; beans less than twice a week; fish less than once a week; sweets or candies, crackers, soda, hamburgers, fried goods, savories, mayonnaise or instant noodles every day.

The resulting score then served as the basis for the classification of that child's food consumption. Consumption was considered to be of low quality when the score was equal to or lesser than three points, of intermediate quality when the score stood between three and six points, and of high-quality when the score was equal to or greater than six points [13]. 
To evaluate maternal attitudes, practices, and beliefs about child feeding and obesity proneness, the Child Feeding Questionnaire (CFQ) was used, developed by Birch et al. [1]. The CFQ was translated to Portuguese, retro-translated, and it was reliably tested $[15,16]$. This questionnaire presents thirty-one items and evaluates the following seven subscales: (1) Perceived responsibility; (2) Perceived parent weight; (3) Perceived child weight; (4) Concern about child weight; (5) Restriction; (6) Pressure to eat; (7) Monitoring.

The first subscale (three items) evaluates how parents regard their responsibility towards their children's eating. The second one (four items) investigates how they approach their body weight throughout their lives. The "Perceived child weight" subscale (six items) is used to evaluate how parents notice their children's body weight history. The fourth subscale (three items) gauges whether parents show any concerns about the risk of their children being overweight, having to go on a diet to maintain their recommended weight, or overeating when they are not around. The "Restriction" (eight items) subscale is used to measure how much parents restrict their children's access to foods. "Pressure to eat" (four items) ascertains whether parents pressure their children to eat larger amounts of food during meals. Finally, the last subscale, Monitoring (three items), is used to verify the extent to which parents supervise their children's food consumption.

Due to the young age of the children in our study, some of the questions of the "perceived child weight" subscale were adapted, and the final questionnaire comprised twenty-nine items (down from thirty-one). Items asking about the child's weight in various phases of elementary school (first to third grade, fourth to sixth grade, and seventh to ninth grade) were replaced by a single question, "How is your child's weight since she/he started the elementary school?"

The questions were answered following a Likert scale of five points. Scores of the items of each subscale were added together, and the mean score of these items represented the sample subscale score.

Descriptive analyses were initially performed. In order to perform univariate and multivariate analysis, the CFQ subscale scores were dichotomized from the median value and grouped as "higher subscale score" (equal to or greater than the median value) or "lower subscale score" (lower than the median value). The Chi-squared test was used to evaluate the relationship between the CFQ subscales (independent variable) and the sociodemographic variables (covariates) with two outcome variables: child nutritional status (non-overweight $x$ overweight) and child quality of food consumption (high-quality food consumption $x$ low and intermediate quality food consumption) (Figure 1).

Multivariate analyses by logistic regression were also performed to obtain the adjusted odds ratios and $95 \% \mathrm{Cl}$. The variables that presented $p \leq 0.20$ in the univariate analysis were included in the multivariate analysis as control variables. In the child nutritional status model, these were: perceived

7 subscales of the Child Feeding

Questionnaire

(Independent variable)

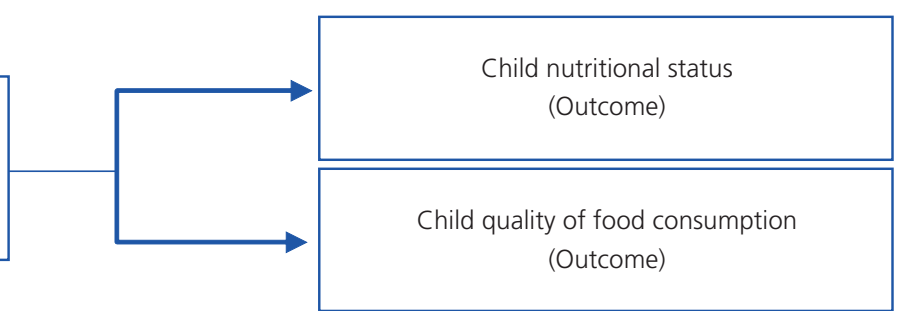

Figure 1. Causal model of research hypotheses with independent variables and outcomes. Brasília (DF), Brazil, 2015. 
responsibility, perceived maternal weight, perceived child weight, concern about child weight, restriction, pressure to eat, child's sex, family income and maternal characteristics (nutritional status and educational level). For the child quality of food consumption model, these control variables were: perceived responsibility, monitoring, child's age, family income and maternal characteristics (age, marital status and educational level).

The Statistical Package for Social Science (SPSS Inc., Chicago, Illinois, United States), version 20.0, was used to analyze the data.

\section{RE S U L T S}

The sample was composed of 563 children and their mothers. The average age of the children was 7.12 years ( $S D \pm 0.85$ years), $51.3 \%$ of which were males. Around one third $(34.1 \%)$ of the analyzed children were overweight (Table 1), with $13.3 \%$ of them being obese. The average maternal age was 37.60 years ( $S D \pm 5.29$ years). Almost $40.0 \%$ of them were overweight (Table 1), with $11.0 \%$ being classified as obese.

The average SCDI score was 8.22 points (SD \pm 3.54 points). The majority of children in the study consumed high-quality food $(77.4 \%)$, while $13.0 \%$ consumed intermediate quality food and $9.6 \%$ consumed low-quality food.

The means of the subscale scores tended to be neutral (close to 3.0). The highest mean score was that of perceived responsibility with 3.96 points, which evidences a greater maternal sense of responsibility towards feeding their children's, food decisions and portion sizes. The monitoring subscale also presented a high mean score of 3.91 points, which evidences a light penchant to this practice, which includes overseeing the child's intake of sweets, snacks, and high-calorie foods (Table 2).

The subscale on the concern about child weight was the only one scoring less than 3.0, with 2.78 points. This shows a low concern among the sample mothers over their child becoming overweight, having to go on a diet to maintain a desirable weight, or eating too much when they aren't present (Table 2).

Mothers with a higher score in the perceived responsibility (69.3\%) and pressure to eat $(62.5 \%)$ subscales had more non-overweight children. There was an association between overweight children and a higher score by the mother in the subscales of perceived maternal weight $(86.5 \%)$, perceived child weight (95.8\%), concern about child weight (76.6\%), and restriction (60.4\%). On the other hand, high-quality food consumption (Table 3 ) was associated with greater scores in the subscales of perception of responsibility (67.7\%) and monitoring (72.0\%).

After accounting for model adjustments, the variables significantly associated with overweight children were: perceived child weight, concern about child weight, perceived responsibility, pressure to eat, maternal nutritional status and educational level (Table 4). Mothers who considered their children to be bigger (Adjusted Odds Ratio [ORaj]=6.60; $\mathrm{Cl}=2.99-14.59)$, mothers who were more concerned about their child's weight (ORaj=3.47; $\mathrm{Cl}=2.25-5.33)$ and who were overweight (ORaj=1.91; $\mathrm{Cl}=1.26-2.91)$ had greater chances of having overweight children. Moreover, mothers with greater perceived responsibility (ORaj=0.57; $\mathrm{Cl}=0.38-0.86$ ), with higher educational level $(\mathrm{ORaj}=0.63 ; \mathrm{Cl}=0.41-0.98)$ and who put more pressure on their children to eat $(\mathrm{ORaj}=0.38$; $\mathrm{Cl}=0.25-0.58$ ) presented lower chances of having overweight children (Table 4). 
Table 1. Descriptive analysis of mothers and their children, 563 students from $1^{\text {st }}$ to $3^{\text {rd }}$ grades of elementary education in private schools. Brasilia (DF), Brazil, 2015.

\begin{tabular}{|c|c|c|}
\hline Study Variables & $\mathrm{n}$ & $\%$ \\
\hline \multicolumn{3}{|l|}{ Child's Sex } \\
\hline Male & 289 & 51.3 \\
\hline Female & 274 & 48.7 \\
\hline \multicolumn{3}{|l|}{ Nutritional status of child } \\
\hline Non-overweight & 371 & 65.9 \\
\hline Overweight & 192 & 34.1 \\
\hline \multicolumn{3}{|l|}{ Mother's nutritional status } \\
\hline Non-overweight & 340 & 60.4 \\
\hline Overweight & 223 & 39.6 \\
\hline \multicolumn{3}{|l|}{ Mother's age } \\
\hline Age $\leq 35$ years & 197 & 35.0 \\
\hline Age $\geq 36$ years & 366 & 65.0 \\
\hline \multicolumn{3}{|l|}{ Marital status } \\
\hline Single/Divorced/Separated/Widowed & 72 & 12.8 \\
\hline Married/Cohabiting & 491 & 87.2 \\
\hline \multicolumn{3}{|l|}{ Mother's educational level } \\
\hline Complete higher education and below & 287 & 51.0 \\
\hline Postgraduate education and above & 276 & 49.0 \\
\hline \multicolumn{3}{|l|}{ Mother's skin color } \\
\hline White & 362 & 64.3 \\
\hline Non White & 201 & 35.7 \\
\hline \multicolumn{3}{|l|}{ Family income ${ }^{a}$} \\
\hline Up to 9 minimum salaries & 180 & 32.0 \\
\hline 9 to 15 minimum salaries & 144 & 25.6 \\
\hline More than 15 minimum salaries & 239 & 42.4 \\
\hline
\end{tabular}

Note: ${ }^{2}$ Minimum salary at the time of the study: 788.00 Brazilian reais (R\$), equivalent to US\$209.60.

Table 2. Descriptive analysis of subscales of the Child Feeding Questionnaire (CFQ). Brasilia (DF), Brazil, 2015.

\begin{tabular}{lc}
\hline Study Variables & Average Points (SD) \\
\hline Perceived responsibility & $3.96(0.72)$ \\
Perceived maternal weight & $3.10(0.41)$ \\
Perceived child weight & $3.00(0.35)$ \\
Concern about child weight & $2.78(1.25)$ \\
Restriction & $3.41(0.72)$ \\
Pressure to eat & $3.27(1.09)$ \\
Monitoring & $3.91(0.79)$ \\
\hline
\end{tabular}

Note: SD: Standard Deviation.

Monitoring and family income were the only variables that had a significant association with high-quality food consumption after the model's adjustment. Mothers who closely monitored their children's eating had 2.79 times more chances $(\mathrm{Cl}=1.83-4.25)$ of having children who consumed 
Table 3. Univariate association of subscales of the Child Feeding Questionnaire, and sociodemographic variables with nutritional status and quality of food consumption. Brasília (DF), Brazil, 2015.

1 of 2

\begin{tabular}{|c|c|c|c|c|c|c|c|c|c|c|}
\hline \multirow[t]{2}{*}{ Variables } & \multicolumn{2}{|c|}{$\begin{array}{l}\text { Non-Overweight } \\
\text { child }\end{array}$} & \multicolumn{2}{|c|}{$\begin{array}{l}\text { Overweight } \\
\text { child }\end{array}$} & \multirow[t]{2}{*}{$p$} & \multicolumn{2}{|c|}{$\begin{array}{l}\text { Child with low or } \\
\text { intermediate quality } \\
\text { food consumption }\end{array}$} & \multicolumn{2}{|c|}{$\begin{array}{c}\text { Child with } \\
\text { high-quality food } \\
\text { consumption }\end{array}$} & \multirow[t]{2}{*}{$p$} \\
\hline & $\mathrm{n}$ & (\%) & $n$ & $(\%)$ & & $\mathrm{n}$ & $(\%)$ & $\mathrm{n}$ & $(\%)$ & \\
\hline \multicolumn{11}{|l|}{ Perceived Responsibility } \\
\hline Higher & 257 & $(69.3)$ & 112 & (58.3) & 0.01 & 74 & $(58.3)$ & 295 & $(67.7)$ & 0.05 \\
\hline Lower & 114 & $(30.7)$ & 80 & $(41.7)$ & & 53 & $(41.7)$ & 141 & $(32.3)$ & \\
\hline \multicolumn{11}{|l|}{ Perceived maternal weight } \\
\hline Higher & 294 & $(79.2)$ & 166 & $(86.5)$ & 0.04 & 102 & $(80.3)$ & 358 & $(82.1)$ & 0.64 \\
\hline Lower & 77 & $(20.8)$ & 26 & (13.5) & & 25 & $(19.7)$ & 78 & $(17.9)$ & \\
\hline \multicolumn{11}{|l|}{ Perceived child weight } \\
\hline Higher & 287 & $(77.4)$ & 184 & $(95.8)$ & $<0.001$ & 109 & $(85.8)$ & 362 & $(83.0)$ & 0.45 \\
\hline Lower & 84 & $(22.6)$ & 8 & $(4.2)$ & & 18 & $(14.2)$ & 74 & $(17.0)$ & \\
\hline \multicolumn{11}{|l|}{ Concern about child weight } \\
\hline Higher & 167 & $(45.0)$ & 147 & (76.6) & $<0.001$ & 68 & $(53.5)$ & 246 & $(56.4)$ & 0.56 \\
\hline Lower & 204 & $(55.0)$ & 45 & (23.4) & & 59 & $(46.5)$ & 190 & $(43.6)$ & \\
\hline \multicolumn{11}{|l|}{ Restriction } \\
\hline Higher & 189 & $(50.9)$ & 116 & $(60.4)$ & 0.03 & 65 & $(51.2)$ & 240 & $(55.0)$ & 0.44 \\
\hline Lower & 182 & $(49.1)$ & 76 & (39.6) & & 62 & $(48.8)$ & 196 & $(45.0)$ & \\
\hline \multicolumn{11}{|l|}{ Pressure to eat } \\
\hline Higher & 232 & $(62.5)$ & 78 & $(40.6)$ & $<0.001$ & 75 & $(59.1)$ & 235 & $(53.9)$ & 0.30 \\
\hline Lower & 139 & $(37.5)$ & 114 & (59.4) & & 52 & $(40.9)$ & 201 & $(46.1)$ & \\
\hline \multicolumn{11}{|l|}{ Monitoring } \\
\hline Higher & 242 & $(65.2)$ & 129 & $(67.2)$ & 0.64 & 57 & $(44.9)$ & 314 & $(72.0)$ & $<0.001$ \\
\hline Lower & 129 & (34.8) & 63 & (32.8) & & 70 & $(55.1)$ & 122 & $(28.0)$ & \\
\hline Child's Sex & & & & & 0.19 & & & & & 0.81 \\
\hline Male & 183 & $(49.3)$ & 106 & $(55.2)$ & & 64 & $(50.4)$ & 225 & $(51.6)$ & \\
\hline Female & 188 & $(50.7)$ & 86 & $(44.8)$ & & 63 & $(49.6)$ & 211 & $(48.4)$ & \\
\hline Child age & & & & & 0.21 & & & & & 0.08 \\
\hline 5 and 6 years-old & 108 & $(29.1)$ & 44 & (22.9) & & 34 & $(26.8)$ & 118 & $(27.1)$ & \\
\hline 7 years-old & 128 & (34.5) & 78 & $(40.6)$ & & 37 & $(29.1)$ & 169 & $(38.7)$ & \\
\hline 8 and 9 years-old & 135 & $(36.4)$ & 70 & (36.5) & & 56 & $(44.1)$ & 149 & $(34.2)$ & \\
\hline Nutritional status of child & & & & & & & & & & 0.57 \\
\hline Non-overweight & & & & & & 81 & $(63.8)$ & 290 & $(66.5)$ & \\
\hline Overweight & & & & & & 46 & $(36.2)$ & 146 & $(33.5)$ & \\
\hline Mother's nutritional status & & & & & $<0.001$ & & & & & 0.45 \\
\hline Non-overweight & 246 & $(66.3)$ & 94 & $(49.0)$ & & 73 & $(57.5)$ & 267 & $(61.2)$ & \\
\hline Overweight & 125 & $(33.7)$ & 98 & $(51.0)$ & & 54 & $(42.5)$ & 169 & $(38.8)$ & \\
\hline Mother's age & & & & & 0.33 & & & & & 0.01 \\
\hline Age $\leq 35$ years-old & 135 & $(36.4)$ & 62 & $(32.3)$ & & 56 & $(44.1)$ & 141 & $(32.3)$ & \\
\hline Age $\geq 36$ years-old & 236 & $(63.6)$ & 130 & $(67.7)$ & & 71 & $(55.9)$ & 295 & $(67.7)$ & \\
\hline
\end{tabular}


Table 3. Univariate association of subscales of the Child Feeding Questionnaire, and sociodemographic variables with nutritional status and quality of food consumption. Brasilia (DF), Brazil, 2015.

2 of 2

\begin{tabular}{|c|c|c|c|c|c|c|c|c|c|c|}
\hline \multirow[t]{2}{*}{ Variables } & \multicolumn{2}{|c|}{$\begin{array}{l}\text { Non-Overweight } \\
\text { child }\end{array}$} & \multicolumn{2}{|c|}{$\begin{array}{l}\text { Overweight } \\
\text { child }\end{array}$} & \multirow[t]{2}{*}{$p$} & \multicolumn{2}{|c|}{$\begin{array}{l}\text { Child with low or } \\
\text { intermediate quality } \\
\text { food consumption }\end{array}$} & \multicolumn{2}{|c|}{$\begin{array}{c}\text { Child with } \\
\text { high-quality food } \\
\text { consumption }\end{array}$} & \multirow[t]{2}{*}{$p$} \\
\hline & $\mathrm{n}$ & $(\%)$ & $\mathrm{n}$ & $(\%)$ & & $\mathrm{n}$ & $(\%)$ & $\mathrm{n}$ & $(\%)$ & \\
\hline Marital status & & & & & 0.91 & & & & & 0.08 \\
\hline $\begin{array}{l}\text { Single/Divorced/Separated/ } \\
\text { Widowed }\end{array}$ & 47 & $(12.7)$ & 25 & $(13.0)$ & & 22 & $(17.3)$ & 50 & $(11.5)$ & \\
\hline Married/Cohabiting & 324 & $(87.3)$ & 167 & $(87.0)$ & & 105 & $(82.7)$ & 386 & $(88.5)$ & \\
\hline Mother's educational level & & & & & 0.05 & & & & & 0.02 \\
\hline $\begin{array}{l}\text { Complete higher education } \\
\text { and below }\end{array}$ & 178 & $(48.0)$ & 109 & $(56.8)$ & & 76 & $(59.8)$ & 211 & $(48.4)$ & \\
\hline $\begin{array}{l}\text { Postgraduate education and } \\
\text { above }\end{array}$ & 193 & $(52.0)$ & 83 & $(43.2)$ & & 51 & $(40.2)$ & 225 & $(51.6)$ & \\
\hline Mother's skin color & & & & & 0.65 & & & & & 0.58 \\
\hline White & 241 & $(65.0)$ & 121 & $(63.0)$ & & 79 & $(62.2)$ & 283 & $(64.9)$ & \\
\hline Non White & 130 & $(35.0)$ & 71 & $(37.0)$ & & 48 & $(37.8)$ & 153 & $(35.1)$ & \\
\hline Family income ${ }^{\mathbf{a}}$ & & & & & 0.05 & & & & & $<0.001$ \\
\hline Up to 9 minimum salaries & 106 & $(28.5)$ & 74 & $(38.5)$ & & 57 & $(44.9)$ & 123 & $(28.2)$ & \\
\hline 9 to 15 minimum salaries & 100 & $(27.0)$ & 44 & $(23.0)$ & & 33 & $(26.0)$ & 111 & $(25.5)$ & \\
\hline $\begin{array}{l}\text { More than } 15 \text { minimum } \\
\text { salaries }\end{array}$ & 165 & $(44.5)$ & 74 & $(38.5)$ & & 37 & $(29.1)$ & 202 & $(46.3)$ & \\
\hline
\end{tabular}

Note: ${ }^{a}$ Minimum salary at the time of the study: 788.00 Brazilian Reais (R\$), equivalent to US\$209.60.

high-quality foods. Mothers whose family income was higher than 15 minimum salaries had almost twice the chance of having children who consumed high-quality foods $(C l=1.14-3.38)$, compared with mothers whose family income was up to 9 minimum salaries (Table 4).

\section{DISCUSSION}

The average score obtained through the School Child Diet Index was 8.22 points, and this study's food consumption evaluation results indicated that $77.4 \%$ of participating children presented high-quality food consumption. These values are higher than those found by Molina et al. [13] in a study on students from public and private schools, where $76.7 \%$ of students were from lower income families. They found an average score of 4.3 points and verified that only $35.1 \%$ of children had high-quality food consumption. This fact can be explained by the higher income and educational level of the population in this study, which naturally leads to mothers with better access to information and healthy foods $[13,17]$.

Women still play a prominent role in childcare and are usually the main players in feeding their children $[9,18,19]$, even with their increased participation in the labor market and the rising difficulty in preparing family meals [20]. We verified that mothers with a greater perceived responsibility were less likely to have overweight children, and that their children tended to have higher quality food 
Table 4. Unadjusted and adjusted odds ratio for presence of overweight and high quality food consumption according to the subscales of the Child Feeding Questionnaire. Brasilia (DF), Brazil, 2015

\begin{tabular}{|c|c|c|c|c|}
\hline \multirow{2}{*}{ Associated Factors } & \multicolumn{2}{|c|}{ Presence of child's overweight } & \multicolumn{2}{|c|}{ Presence of high-quality food consumption } \\
\hline & OR $(95 \% \mathrm{Cl})$ & Adjusted OR $(95 \% \mathrm{Cl})^{\mathrm{a}}$ & OR $(95 \% \mathrm{Cl})$ & Adjusted OR $(95 \% \mathrm{Cl})^{\mathbf{b}}$ \\
\hline \multicolumn{5}{|l|}{ Perceived responsibility } \\
\hline Higher & $0.62(0.43-0.89)$ & $0.57(0.38-0.86)$ & $1.50(1.00-2.25)$ & $1.46(0.94-2.27)$ \\
\hline Lower & 1 & 1 & 1 & 1 \\
\hline \multicolumn{5}{|l|}{ Perceived maternal weight } \\
\hline Higher & $1.67(1.03-2.71)$ & $1.04(0.59-1.85)$ & & \\
\hline Lower & 1 & 1 & & \\
\hline \multicolumn{5}{|l|}{ Perceived Child weight } \\
\hline Higher & $6.73(3.18-14.23)$ & $6.60(2.99-14.59)$ & & \\
\hline Lower & 1 & 1 & & \\
\hline \multicolumn{5}{|l|}{ Concern about child weight } \\
\hline Higher & $3.99(2.70-5.90)$ & $3.47(2.25-5.33)$ & & \\
\hline Lower & 1 & 1 & & \\
\hline \multicolumn{5}{|l|}{ Restriction } \\
\hline Higher & $1.47(1.03-2.09)$ & $1.53(1.00-2.35)$ & & \\
\hline Lower & 1 & 1 & & \\
\hline \multicolumn{5}{|l|}{ Pressure to eat } \\
\hline Higher & $0.41(0.29-0.59)$ & $0.38(0.25-0.58)$ & & \\
\hline Lower & 1 & 1 & & \\
\hline \multicolumn{5}{|l|}{ Monitoring } \\
\hline Higher & & & $3.16(2.10-4.75)$ & $2.79(1.83-4.25)$ \\
\hline Lower & & & 1 & 1 \\
\hline \multicolumn{5}{|l|}{ Child's sex } \\
\hline Male & 1 & 1 & & \\
\hline Female & $0.79(0.56-1.12)$ & $0.68(0.46-1.02)$ & & \\
\hline \multicolumn{5}{|l|}{ Child age } \\
\hline 5 and 6 years-old & & & 1 & 1 \\
\hline 7 years-old & & & $1.32(0.78-2.22)$ & $1.27(0.73-2.21)$ \\
\hline 8 and 9 years-old & & & $0.77(0.47-1.25)$ & $0.74(0.44-1.24)$ \\
\hline \multicolumn{5}{|l|}{ Mother's nutritional status } \\
\hline Non-overweight & 1 & 1 & & \\
\hline Overweight & $2.05(1.44-2.93)$ & $1.91(1.26-2.91)$ & & \\
\hline \multicolumn{5}{|l|}{ Mother's age } \\
\hline Age $\leq 35$ years-old & & & 1 & 1 \\
\hline Age $\geq 36$ years & & & $1.65(1.10-2.47)$ & $1.34(0.86-2.09)$ \\
\hline \multicolumn{5}{|l|}{ Marital status } \\
\hline Single/Divorced/Separated/Widowed & & & 1 & 1 \\
\hline Married/Stable Union & & & $1.62(0.94-2.79)$ & $1.15(0.64-2.09)$ \\
\hline \multicolumn{5}{|l|}{ Mother's educational level } \\
\hline Complete higher education and below & 1 & 1 & 1 & 1 \\
\hline Postgraduate education and above & $0.70(0.49-1.00)$ & $0.63(0.41-0.98)$ & $1.59(1.06-2.37)$ & $1.21(0.76-1.91)$ \\
\hline
\end{tabular}


Table 4. Unadjusted and adjusted odds ratio for presence of overweight and high quality food consumption according to the subscales of the Child Feeding Questionnaire. Brasilia (DF), Brazil, 2015.

2 of 2

\begin{tabular}{|c|c|c|c|c|}
\hline \multirow{2}{*}{ Associated Factors } & \multicolumn{2}{|c|}{ Presence of child's overweight } & \multicolumn{2}{|c|}{ Presence of high-quality food consumption } \\
\hline & OR $(95 \% \mathrm{Cl})$ & Adjusted OR $(95 \% \mathrm{Cl})^{\mathrm{a}}$ & OR $(95 \% \mathrm{Cl})$ & Adjusted OR $(95 \% \mathrm{Cl})^{\mathbf{b}}$ \\
\hline \multicolumn{5}{|l|}{ Family income } \\
\hline Up to 9 minimum salaries & 1 & 1 & 1 & 1 \\
\hline 9 to 15 minimum salaries & $0.63(0.40-1.00)$ & $0.70(0.41-1.20)$ & $1.56(0.95-2.57)$ & $1.30(0.75-2.23)$ \\
\hline More than 15 minimum salaries & $0.64(0.43-0.96)$ & $0.89(0.54-1.45)$ & $2.53(1.58-4.05)$ & $1.96(1.14-3.38)$ \\
\hline
\end{tabular}

Note: OR: Odds Ratio. Cl: Confidence Interval. Adjusted ORa: Odds Ratio adjusted by logistic regression for perceived responsibility, perceived maternal weight, perceived child weight, concern about the child's weight, restriction, pressure to eat, child's sex, family income and maternal characteristics (nutritional status and educational level). Adjusted ORb: Odds Ratio adjusted by logistic regression for perceived responsibility, monitoring, child's age, family income and maternal characteristics (age, marital status, educational level).

consumption, although this association was not significant in the multivariate analysis. This study suggests that this perceived responsibility contributes to the high dietary scores mentioned above and to an adequate control of the child's weight, within healthy parameters. Mothers who feel more responsible tend to be more alert towards their children's eating habits, and care for the quality and quantity of food offered to the child [1]. Parents have a key role in determining which foods are available for the child's consumption, as they are usually responsible for grocery shopping. Being aware of the quality of food offered is important, as it can have an influence on a child's eating habits and preferences [21]. Unlike the positive results found in the present study, however, Spruijt-Metz et al. [22] found that perceived responsibility can positively correlate with the practices of restriction and pressure to eat, and new studies are needed in order to clarify these correlations.

It was also found that overweight mothers and mothers who perceive their own body weight as larger tend to have overweight children. Several factors can explain this phenomenon, such as the genetic propensity for weight gain and eating habits shared by mothers and children $[19,23]$. Mothers of overweight children noticed excess weight in children and were more concerned with this fact. Faith et al. [23] also noticed an association between the results of these two subscales and the BMI. In a study with mothers of girls, Francis et al. [24] observed this same behavior, which is a predictor of maternal restriction practices.

Mothers with higher scores at the restriction subscale tend to have overweight children. Even though this association was not significant in the multivariate analysis, it echoes findings of previous studies $[23,25]$. Although well-intentioned, restrictive dietary practices may incur opposite consequences, and are associated with child weight gain, a higher attraction, preference and consumption of restricted foods, and the habit of eating even in the absence of hunger $[9-11,21,23,26,27]$. The use of restriction as a practice of control is usually chronic and continuous, and leads the child to lose the ability to regulate the innate sensations of hunger and satiety, resulting in the increased consumption of restricted foods when they are available $[8,25,27]$.

It was observed that mothers who pressured their children to eat had less occurrences of overweight children. The negative correlation between the subscale pressure to eat and the child's BMI has been previously found $[19,26,28]$. Pressure to eat, however, is not recommended as a dietary practice because it brings long-term consequences in the eating habits of the individual [8]. This 
practice can lead the individual, even as an adult, to avoid foods she or he was pressured to eat as a child. It can also harm the self-regulation of the child's food consumption, and is associated with food neophobia, the tendency to avoid the consumption of unknown foods $[4,9,29,30]$.

It was also observed that mothers who monitored more their child's eating had higher chances of having their children consume high-quality food. Monitoring can be a discreet form of restraint used when the child acquires greater control over their own food consumption $[19,28]$. Although a relation between monitoring and the nutritional status of children was not noticeable in this study, Faith et al. [23], in a longitudinal study, found that reduced monitoring on child feeding predicted an increase in the child's BMI z-scores. Thus, it can be suggested that some parental practices, such as monitoring, can be beneficial to a child's dietary behaviors, improving eating habits and reducing the child's risk of being overweight [19,31].

This study is limited by the use of a qualitative Food Frequency Questionnaire, which did not allow for information on the serving sizes consumed by the children to be collected. In addition, food consumption during school period could have been asked for teachers or school supervisors. However, the researchers decided to interview only the mothers due to the logistics of the study. Furthermore, maternal practices on child feeding control were only reported by the mothers, which may generate biases since the context of the meals was not directly observed by the researchers. Also, the study has limited external validity given that the sample consists of children from private schools, with richer and more educated families. In addition, given the high prevalence of overweight children, the strength of associations may be overestimated for the nutritional status results [32].

It is suggested that future studies that evaluate this thematic in Brazil have a longitudinal character and evaluate a more diverse sample. Despite the limitations, this is an innovative study that brings new data related to maternal attitudes, practices, and beliefs related to schoolchildren feeding and nutritional status.

\section{CONCLUSION}

It was observed that maternal attitudes, practices and beliefs about child feeding had a noticeable relation with the child's food consumption and nutritional status. The nutritional status of the child can be affected positively by maternal responsibility towards the child's feeding, while the quality of food consumption can be higher when mothers monitor more their children's food consumption. Therefore, nutritional interventions, then, should focus on stimulating the parents' sense of responsibility for the child's nutrition, as well as promoting frequent monitoring of the child's food intake and less restriction and pressure to eat, since maternal attitudes, practices and beliefs related to child feeding can have a profound impact on the child's food consumption for the rest of her or his life.

\section{CONTRIBUTORS}

J PEDROSO contributed to the study design; data collection, analysis and interpretation; and manuscript writing. N TORAL contributed to data analysis and interpretation; and manuscript writing. MB GUBERT contributed to study design; data analysis and interpretation; and manuscript writing. All authors have critically reviewed and approved the final content of this paper. 


\section{REFERENCES}

1. Birch LL, Ficher JO, Grimm-Thomas K, Markey CN, Sawyer R, Johnson SL. Confirmatory factor analysis of the Child Feeding Questionnaire: A measure of parental attitudes, beliefs and practices about child feeding and obesity proneness. Appetite. 2001;36(3):201-10. http://dx.doi.org/10.1006/appe.2001.0398

2. Giacomossi MC, Zanella T, Höfelmann DA. Percepção materna do estado nutricional de crianças de creches de cidade do Sul do Brasil. Rev Nutr. 2011;24(5):689-702. http://dx.doi.org/10.1590/S1415-52 732011000500003

3. Pérez-Escamilla R, Segura-Pérez $S$, Lott $M$. Feeding guidelines for infants and young toddlers: A responsive parenting approach. Nutr Today. 2017;52(5):223-31.

4. Yang W, Burrows T, MacDonald-Wicks L, Williams LT, Collins CE, Chee WSS. Parent-child feeding practices in a developing country: Findings from the Family Diet Study. Appetite. 2018;125:90-7. http://dx.doi.org/10. 1016/j.appet.2018.01.037

5. Adamo KB, Brett KE. Parental perceptions and childhood dietary quality. Matern Child Health J. 2014;18(4):978-95. http://dx.doi.org/10.1007/s10995-013-1326-6

6. Birch LL, Ficher JO. Mothers' child-feeding practices influence daughters' eating and weight. Am J Clin Nutr. 2000;71(5):1054-61. http://dx.doi.org/10.1093/ajcn/71.5.1054

7. Viana V, Candeias L, Rego C, Silva D. Comportamento alimentar em crianças e controlo parental: uma revisão da bibliografia. Alim Hum. 2009;15(1):9-16.

8. Loth KA, MacLehose RF, Fulkerson JA, Crow S, Neumark-Sztainer D. Eat this, not that! Parental demographic correlates of food-related parenting practices. Appetite. 2013;60:140-7. http://dx.doi.org/10.1016/j.appet. 2012.09.019

9. McPhie S, Skouteris H, Daniels L, Jansen E. Maternal correlates of maternal child feeding practices: A systematic review. Matern Child Nutr. 2014;10:18-43. http://dx.doi.org/10.1111/j.1740-8709.2012.00452.x

10. Corsini N, Kettler L, Danthiir V, Wilson C. Parental feeding practices to manage snack food intake: Associations with energy intake regulation in young children. Appetite. 2018;123:233-40. http://dx.doi.org/10.1016/j. appet.2017.12.024

11. Norman J, Kelly B, McMahon AT, Boyland E, Baur LA, Chapman K, et al. Children's self-regulation of eating provides no defense against television and online food marketing. Appetite. 2018;125:438-44. http://dx. doi.org/10.1016/j.appet.2018.02.026

12. World Health Organization. WHO AnthroPlus for personal computers Manual: Software for assessing growth of the world's children and adolescents. Geneva: WHO; 2009.

13. Molina MCB, Lopéz PM, Faria CP, Cade NV. Preditores socioeconômicos da qualidade da alimentação de crianças. Rev Saúde Pública. 2010;44(5):785-92. http://dx.doi.org/10.1590/S0034-89102010005000036

14. Ministério da Saúde (Brasil). Guia alimentar para a população brasileira: promovendo a alimentação saudável. Brasília: Ministério da Saúde; 2014 [citado 2016 jun 10]. Disponível em: http://189.28.128.100/nutricao/ docs/geral/guia_alimentar_conteudo.pdf

15. Cruz ISM. O uso de um questionário de alimentação para o estudo de atitudes, crenças e práticas dos pais em relação à alimentação e propensão à obesidade [Dissertação]. Ribeirão Preto: Faculdade de Filosofia, Ciências e Letras de Ribeirão Preto, Universidade de São Paulo; 2009.

16. Lorenzato L, Cruz ISM, Costa TMB, Almeida SS. Translation and cross-cultural adaptation of a Brazilian version of the Child Feeding Questionnaire. Paidéia. 2017;27(66):33-42. http://dx.doi.org/10.1590/1982-43 272766201705

17. Morimoto JM, Latorre MRDO, César CLG, Carandina L, Barros MBA, Goldbaum M, et al. Fatores associados à qualidade da dieta de adultos residentes na Região Metropolitana de São Paulo, Brasil, 2002. Cad Saúde Pública. 2008;24(1):169-78. http://dx.doi.org/10.1590/S0102-311X2008000100017

18. Blissett J, Meyer C, Haycraft E. Maternal and paternal controlling feeding practices with male and female children. Appetite. 2006;47(2):212-9. http://dx.doi.org/10.1016/j.appet.2006.04.002

19. Viana $V$, Franco T, Morais C. O estado ponderal e o comportamento alimentar de crianças e jovens: influência do peso e das atitudes de controlo da mãe. Psicol Saúde Doenças. 2011;12(2):267-79.

20. Rinaldi AEM, Pereira AF, Macedo CS, Mota JF, Burini RC. Contribuições das práticas alimentares e inatividade física para o excesso de peso infantil. Rev Paul Pediatr. 2008;26(3):271-7. http://dx.doi.org/10.1590/S0103-05 822008000300012 
21. Rhee K. Childhood overweight and the relationship between parent behaviors, parenting style, and family functioning. Ann Am Acad Pol Soc Sci. 2008;615(1):11-37. http://dx.doi.org/10.1177/0002716207308400

22. Spruijt-Metz D, Lindquist CH, Birch LL, Fisher JO, Goran MI. Relation between mothers' child-feeding practices and children's adiposity. Am J Clin Nutr. 2002;75:581-6. http://dx.doi.org/10.1093/ajcn/75.3.581

23. Faith MS, Berkowitz RI, Stallings VA, Kerns J, Storey M, Stunkard AJ. Parental feeding attitudes and styles and child body mass index: Prospective analysis of a gene-environment interaction. Pediatrics. 2004;114(4):e429-36. http:// dx.doi.org/10.1542/peds.2003-1075-L

24. Francis LA, Hofer SM, Birch LL. Predictors of maternal child-feeding style: Maternal and child characteristics. Appetite. 2001;37:231-43. http://dx.doi.org/10.1006/appe.2001.0427

25. May AL, Donohue M, Scanlon KS, Sherry B, Dalenius K, Faulkner P, et al. Child-feeding strategies are associated with maternal concern about children becoming overweight, but not children's weight status. J Am Diet Assoc. 2007;107(7):1167-74. http://dx.doi.org/10.1016/j.jada.2007.04.009

26. Birch LL, Fisher JO, Davison KK. Learning to overeat: Maternal use of restrictive feeding practices promotes girls' eating in the absence of hunger. Am J Clin Nutr. 2003;78:215-20. http://dx.doi.org/10.1093/ajcn/78. 2.215

27. Rollins BY, Loken E, Savage JS, Birch LL. Effects of restriction on children's intake differ by child temperament, food reinforcement, and parent's chronic use of restriction. Appetite. 2014;73:31-9. http://dx.doi.org/10.10 16/j.appet.2013.10.005

28. Webber L, Cooke L, Hill C, Wardle J. Child adiposity and maternal feeding practices: A longitudinal analysis. Am J Clin Nutr. 2010;92:1423-8. http://dx.doi.org/10.3945/ajcn.2010.30112

29. Faith MS, Heo M, Keller KL, Pietrobelli A. Child food neophobia is heritable, associated with less compliant eating, and moderates familial resemblance for BMI. Obesity. 2013;21(8):1650-5. http://dx.doi.org/10.1002/ oby. 20369

30. Mitchell GL, Farrow C, Haycraft E, Meyer C. Parental influences on children's eating behaviour and characteristics of successful parent-focussed interventions. Appetite. 2013;60:85-94. http://dx.doi.org/10. 1016/j.appet.2012.09.014

31. Rhee KE, Appugliese DP, Prisco A, Kaciroti NA, Corwyn RF, Bradley RH, et al. Controlling maternal feeding practices associated with decreased dieting behavior in 6th grade children. J Am Diet Assoc. 2010;110(4):619-23. http://dx.doi.org/10.1016/j.jada.2009.12.018

32. Davies HTO, Crombie IK, Tavakoli M. When can odds ratios mislead? BMJ. 1998;316(7136):989-91. http:// dx.doi.org/10.1136/bmj.316.7136.989 